\title{
Educação permanente no âmbito da Atenção Primária a Saúde: relato de experiência.
}

\author{
Amanda Tamires Drumond Vilas Boas Tavares, Rafaela Magalhães Fernandes Saltarelli, Láyza Said \\ Bernardes
}

\section{Resumo}

Atualmente, a formação dos profissionais de saúde está voltada para o modelo biomédico hospitalocêntrico, fazendo com que eles se apropriem de diversas técnicas, não aprendendo a lidar com a subjetividade humana. Assim, faz-se necessário modificar o sistema de formação dos mesmos, permitindo a transformação de suas práticas e a organização dos processos de trabalho. A Educação Permanente (EP) é uma ferramenta essencial na Atenção Primária à saúde (APS), pois possibilita que os profissionais de saúde problematizem, articulem entre si e desenvolvam o acolhimento e o cuidado às várias dimensões de saúde das pessoas. Dessa forma, aumenta a resolução dos problemas nos serviços de saúde e conseguinte, melhora a qualidade da assistência. Relatar uma experiência exitosa de práticas de EP em uma Unidade Básica de Saúde (UBS) do município de Viçosa, MG. Trata-se de um relato descritivo de um projeto de extensão intitulado "Educação Permanente no âmbito da Atenção Primária a Saúde: subsídios para a melhoria da assistência", vinculado a Universidade Federal de Viçosa (UFV). As atividades foram desenvolvidas no período de março a junho de 2016, durante o Estágio Supervisionado em Saúde Coletiva, do curso de enfermagem da UFV. A primeira etapa consistiu na realização de um Diagnóstico Situacional e Administrativo com o objetivo de levantar os principais problemas existentes na UBS. A ausência de atividades de EP foi elencada como problema prioritário. A segunda etapa foi o desenvolvimento de um planejamento estratégico de intervenção, juntamente com a equipe. A terceira etapa consistiu na operacionalização das ações para implementar a EP como o levantamento de temas de interesses dos profissionais da UBS, por meio de uma entrevista aberta e individual, definição de metodologias para abordar esses temas escolhidos e escolha de estratégias de avaliação. A observação participante foi utilizada para registrar todas as atividades. Foi definida uma agenda fixa na UBS para a EP, sendo as sextas-feiras, no período da tarde. Seis encontros foram realizados com os seguintes temas: "Higienização de estabelecimentos de saúde e saúde do trabalhador", "Primeiros Socorros", "Feridas", "Calendário Vacinal", "Doenças Alérgicas", "Trabalho em equipe e Motivação". Utilizou-se de dinâmicas e exposições dialógicas com base na teoria da problematização, de Paulo Freire. A problematização implica corresponsabilidade entre os atores em todas as etapas do processo de ensino-aprendizagem, valorizando o saber do educador e do educando. A EP realizada na própria UBS demonstrou ser bastante exitosa, pois foi possível construir um ambiente propício ao diálogo e fortalecimento do processo de ensino aprendizagem. Todos profissionais participaram das atividades propostas e demonstraram um grande envolvimento com as mesmas. Fizeram perguntas e tiveram a liberdade de expor suas singularidades e dúvidas, sendo um local de aprendizado, corroborando para um melhor conhecimento sobre os temas trabalhados e conseguinte, a melhoria da qualidade da assistência. Além disso, a atividade permitiu uma maior integração entre os membros da equipe. Percebe-se uma necessidade de se desenvolver meios que permitam o alcance da realização da EP na APS, realizado continuamente, propiciando assim, pleno desenvolvimento da educação e transformação destes profissionais.

Descritores: Educação; Profissionais de saúde; Atenção Primária à Saúde. 